\title{
A COMPARATIVE STUDY OF LITERACY STATUS BETWEEN EAG AND NON-EAG STATES OF INDIA WITH SPECIAL REFERENCE TO EAG STATES (2001-2011)
}

\author{
Md. Selim Reja* \\ and \\ ShewliShabnam**
}

\begin{abstract}
Literacy is considered as one of the key foundation stones for any development process in the society. It increases the capabilities of individuals, families and communities to access health, educational, political, economic and cultural opportunities and services. This study deals with the literacy status of Empowered Action Group (EAG) States of India. It highlights the gender disparity in literacy, rural-urban differential in literacy and literacy differential among the various social groups in EAG as well as Non-EAG States. It also examines the district level literacy variations especially in EAG States. The study uses the Census data of 2001 and 2011 to fulfil the objectives. It finds that though the disparity in literacy rates between EAG and Non-EAG States is still substantial, between 2001 and 2011 the growth of literacy rate,especiallyin rural areas, is found to be much higher in EAG States than Non-EAG States. More importantly, between 2001 and 2011, gender disparity in literacy rate has decreased in both EAG and Non-EAG States.
\end{abstract}

\section{Introduction}

Literacy is a human right and the foundation of all developmental processes. It has an intrinsic importance because it increases a person's freedom and sense of security. It also hasan instrumental significance as it strengthens the capabilities of individuals, families and communities to access health, educational, political,economic and cultural opportunities and services (UNESCO, 2005). Low level of literacy and elementary education is considered as one of the basic reasonsfor India's poverty and inability to utilise the opportunities of globalisation. In 1991, when India liberalised its economy, its adult literacy rate was significantly lower compared to the so-called 'East Asian Tigers' South Korea, Hong Kong,Singapore and Taiwan. For example, the adult literacy rate in Taiwan in

*Assistant Professor, Department of Geography, University B.T. \& Evening College, Coochbehar, West Bengal.

** Assistant Professor, Department of Geography, Bidhannagar College, Kolkata, West Bengal. 
1990 was 93 per cent compared to 48 per cent in India (World Bank, 1992). Modern industries demand many basic skills for which elementary education is essential and secondary education is very helpful. New technologies cannot be used in agriculture if amajority of farmerscannotread, write or count or cannot follow printed or handwritten instructions (Sen, 1994). But unfortunately, 26 percent of the total population and 31.1 per cent of rural population of India are still illiterate according to the Census of India, 2011 (Registrar General and Census Commissioner, 2011). Here, we have to keep in mind that the census definition of 'literacy' is much narrow in comparison to the comprehensive definition of 'functional literacy' given by the UNESCO in 1978: " A person is functionally literate who can engage in all those activities in which literacy is required for effective functioning of his group or community and also for enabling him to continue to use reading, writing and calculation for his own and the community's development" (UNESCO, 2005). The latest Indian Census has identified 'a person aged 7 years and above who can both read and write with understanding in any language as literate.' Also, it is not necessary for a person to have received any formal education or passed any minimum educational standard for being treated as'literate'. Therefore, it is clear that even taking the minimalist notion of literacy, India's performance in eliminating illiteracy is surprisingly poor.

Elementary education in India has never been prioritised by the elitist ruling class of India and the effect is visible in the abysmal low level of literacy rate in many parts of the country. The condition is worse for females and those belong to backward communities. In this context, it is important to find out the changes in the level of literacy, gendergap and social group differentials in literacy in the backward States of India. The focus of this study is on less developed Empowered Action Group (EAG) States of India, namely, Rajasthan, Bihar, UttarPradesh,Madhya Pradesh, Odisha, Chhattisgarh, Uttaranchal and J harkhand. These States have lagged behind in achieving various socio-demographic goals and therefore, they are chosen astargetsfora variety of government health and family planning programmes. In order to achieve national goals, it is imperative that theEAG States must perform better. Our study has been carried out at district level as districtsorgroup of districtscan be singled out as the smallest effective units for regional planning. The main objectives of the study are given below.

1. To find out the rural-urban differential, gender disparity and social group differentials in the level of literacy in EAG and non-EAG States of India;

2. To describe the decadal growth rate (2001-2011) of literacy in EAG and NonEAGStates.

3. To understand the pattern of literacy rate in the districts of EAG States and also the decadal (2001-2011) growth differential.

4. To observe the literacy status of two very disadvantaged groups of Indian population - rural Scheduled Caste (SC) 
females and rural Scheduled Tribe (ST) females in the districts of EAG States of India.

\section{Methodology}

2001 and 2011 Census data of India has been used for this study. For 2001 data, we have used Table C-8 from C-series and data of 2011 has been taken from Primary Census Abstract of India. Primary Census Abstract of each EAG State has been used for district level analysis.

In this paper literacy rate has been computed as:

Literacy rate $=\frac{\begin{array}{c}\text { Number of literate } \\ \text { persons aged } 7 \text { years } \\ \text { and above*100 }\end{array}}{\begin{array}{c}\text { Population aged } 7 \\ \text { years and above }\end{array}}$

The decadal growth rate in literacy between 2001 and 2011 has been calculated as:

$$
\mathrm{GRL}=\frac{\begin{array}{c}
\text { Literacy rate of } 2011 \text { - Literacy } \\
\text { rate of } 2001 * 100
\end{array}}{\text { Literacy rate of } 2001}
$$

where, GRL refers to the decadal growth rate in literacy of a region e.g., a district.

To show the gender disparity in literacy wehave used a disparity index proposed by David V.Sopher (1974). The index measures disparity between two groups in their possession of a particular property (in this case the literacy rate between males and females). According to Sopher,the disparity index (DI) can be calculated by the following formula:
$\mathrm{DI}=\log \left(\mathrm{X}_{2} / \mathrm{X}_{1}\right)+\log \left[\left(\mathrm{Q}-\mathrm{X}_{1}\right) /\left(\mathrm{Q}-\mathrm{X}_{2}\right)\right]$, where $X_{2}>X_{1}$ and $Q=100$

As male literacy is higher than female, female literacy rate should be taken as $X_{1}$ and male literacy rate as $X_{2}$. In case of perfect equality, the value of $\mathrm{DI}$ will be zero. Also, higher the value of $\mathrm{DI}$, greater is the extent of disparity. Later Kundu and Rao (1983) have shown that the above index fails to satisfy the additive monotonocity axiom. So they proposed a modification to this Index as given below.

$$
\mathrm{DI}=\log \left(\mathrm{X}_{2} / \mathrm{X}_{1}\right)+\log \left[\left(\mathrm{Q}-\mathrm{X}_{1}\right) /\left(\mathrm{Q}-\mathrm{X}_{2}\right)\right]
$$
where $X_{2}>X_{1}$ and $Q=200$

We have used the above modified Sopher's techniqueto computegender disparity index.

To measure the rural-urban differential in literacy rate, we have used rural-urban differential indexas given below.

$$
I D=\quad \frac{U-R}{T}
$$

Where, $I D=$ index of rural-urban differential in literacy

$\mathrm{U}=$ percentage of literates in urban population

$R=$ percentage of literates in rural population

$\mathrm{T}=$ percentage of literates to total population

The above index is a popular index to show the rural-urban disparity in any field (e.g., 
literacy, health, etc.). The justification for using this index has been discussed elaborately by Krishnan and Shyam (1978:14). However, ruralurban differential in literacy could have also been shown using Sopher's index.

\section{Results and Discussion}

Status of Literacy: India, EAG and Non-EAG

States: In this section we have presented the overall picture of literacy of EAG States among rural, urban and total population. Forcomparison purpose, the average literacy rate of India, EAG and Non-EAG States have also been shown. According to 2011 census, the average literacy rate of EAG States is 67.43 per cent, 10.17 percentage points lower than the literacy rate of Non-EAG States and 6.61 percentage points lower than the national average. In 2001, the average literacy rate of EAG States was 57.22 per cent and the difference in literacy rate between the EAG and Non-EAG States was 13.42 percentage points. Among the EAG States, the highest level of literacy is found in Uttaranchal and the lowest in Bihar in both 2001 and 2011 censuses. Though in Bihar the literacy rate has increased to 14.8 percentage points between 2001 and 2011, only 61.8 per cent of the population is counted as literate during 2011 census.

\section{Map 1: EAG States in India}

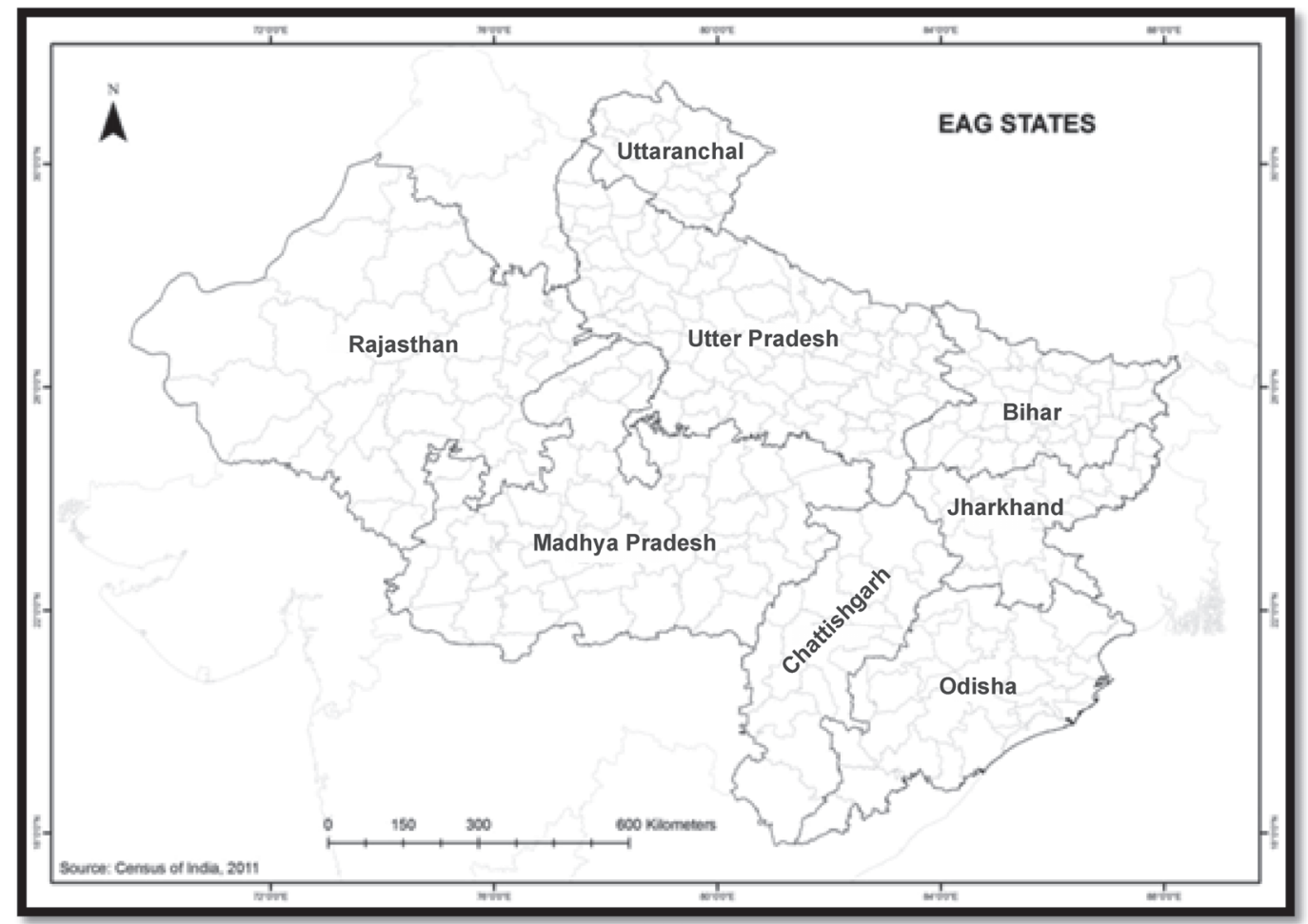

Journal of Rural Development, Vol. 36, No. 4, October-December : 2017 
The difference in literacy rate between EAG and Non-EAGStatesiscomparatively higher among females than males. This will be discussed with the help of Gender Disparity Index later. In 2011 except Bihar all other EAG States show the male literacy rate above $75 \mathrm{per}$ cent but none of the EAG States shows female literacy rate above 75 per cent [Table 1(a)]. In Bihar and Rajasthan, almost half of the women are found illiterate during the latest census. Table 1(b) reveals that among the rural population more than half of the women are illiterate in three EAG States, namely, Rajasthan (54.2 per cent), J harkhand (51.09 per cent) and Bihar (51.0 per cent) in 2011. In 2001, female literacy rates in these three States were 37.33, 29.89 and 29.61 per cent, respectively. The average male literacy rate in rural areas of the EAG Stateshasincreased from 66.79 percent in 2001 to 75.01 per cent in 2011. As per 2011 census among EAG States, the rural male literacy rate is the highest in Uttaranchal (86.62 percent) and the lowest in Bihar (69.67 percent). The level of literacy among urban population is much higher than therural population.With thehelp of Rural-Urban Differential Indexit will be discussed in detail in the later part of this paper. In 2011 the average literacy rate of the EAG States was 64.0 per cent among the rural population and 79.12 percent among the urban population. For Non- EAG States, it was 71.77 per cent among the rural population and 86.31 per cent among the urban population. In 2001, among the EAG States both urban male and female literacy rate wasthe lowest in Uttar Pradesh and the highest in Orissa. These two States also hold their respective positions in 2011 census. From Table $1(\mathrm{a}), 1$ (b) and 1 (c) it is markedly visible that the literacy rate ofUttaranchal is substantially higher than the other EAG States.

Table1(a): Literacy Rate (\%) in India, EAG and Non-EAG States in 2001 and 2011: Total

\begin{tabular}{|lcccccc|}
\hline India/State & \multicolumn{2}{c}{ Total Literacy } & \multicolumn{2}{c|}{ Male Literacy } & \multicolumn{2}{c|}{ Female Literacy } \\
\hline & 2001 & 2011 & 2001 & 2011 & 2001 & 2011 \\
\hline India & 64.84 & 74.04 & 75.26 & 82.14 & 53.67 & 65.46 \\
Non-EAG States & 70.64 & 77.60 & 79.25 & 83.91 & 61.53 & 71.03 \\
EAGStates & 57.22 & 67.43 & 70.09 & 77.35 & 43.21 & 56.81 \\
Bihar & 47.00 & 61.80 & 59.68 & 71.20 & 33.12 & 51.50 \\
Jharkhand & 53.56 & 66.41 & 67.30 & 76.84 & 38.87 & 55.42 \\
Rajasthan & 60.41 & 66.11 & 75.70 & 79.19 & 43.85 & 52.12 \\
UttarPradesh & 56.27 & 67.68 & 68.82 & 77.28 & 42.22 & 57.18 \\
Odisha & 63.08 & 72.87 & 75.35 & 81.59 & 50.51 & 64.01 \\
MadhyaPradesh & 63.74 & 69.32 & 76.06 & 78.73 & 50.29 & 59.24 \\
Chhattisgarh & 64.66 & 70.28 & 77.38 & 80.27 & 51.85 & 60.24 \\
Uttaranchal & 71.62 & 78.82 & 83.28 & 87.40 & 59.63 & 70.01 \\
\hline
\end{tabular}

Source: Computed from Primary Census Abstract, Census of India 2011 and 2001, Table C-8. 
Table1 (b): Literacy Rate (\%) in India, EAG and Non-EAG States in 2001 and 2011: Rural

\begin{tabular}{|lcccccc|}
\hline India/State & \multicolumn{2}{c}{ Total Literacy } & \multicolumn{2}{c|}{ Male Literacy } & \multicolumn{2}{c|}{ Female Literacy } \\
\hline & 2001 & 2011 & 2001 & 2011 & 2001 & 2011 \\
\hline India & 58.74 & 67.77 & 70.70 & 78.60 & 46.13 & 58.80 \\
Non-EAG States & 64.38 & 71.77 & 74.42 & 79.47 & 53.99 & 63.84 \\
EAGStates & 52.70 & 64.00 & 66.79 & 75.01 & 37.53 & 52.26 \\
Bihar & 43.92 & 59.78 & 57.09 & 69.67 & 29.61 & 49.00 \\
Jharkhand & 45.74 & 61.11 & 60.94 & 72.86 & 29.89 & 48.91 \\
Rajasthan & 55.34 & 61.44 & 72.16 & 76.16 & 37.33 & 45.80 \\
UttarPradesh & 52.53 & 65.46 & 66.59 & 76.33 & 36.90 & 53.65 \\
Odisha & 59.84 & 70.22 & 72.93 & 79.65 & 46.66 & 60.74 \\
Madhya Pradesh & 57.80 & 63.94 & 71.70 & 74.74 & 42.76 & 52.43 \\
Chhattisgarh & 60.48 & 65.99 & 74.09 & 76.98 & 46.99 & 55.06 \\
Uttaranchal & 68.07 & 76.31 & 81.78 & 86.62 & 54.70 & 66.18 \\
\hline
\end{tabular}

Source: Computed from Primary Census Abstract, Census of India 2011 and 2001, Table C-8.

Table1(c): Literacy Rate (\%) in India, EAG and Non-EAG States in 2001 and 2011: Urban

\begin{tabular}{|lcccccc|}
\hline India/State & \multicolumn{2}{c}{ Total Literacy } & \multicolumn{2}{c|}{ Male Literacy } & \multicolumn{2}{c|}{ Female Literacy } \\
\hline & 2001 & 2011 & 2001 & 2011 & 2001 & 2011 \\
\hline India & 79.92 & 84.11 & 86.27 & 89.70 & 72.86 & 79.90 \\
Non-EAG States & 82.23 & 86.31 & 87.94 & 90.44 & 75.94 & 81.92 \\
EAGStates & 74.74 & 79.12 & 82.58 & 85.03 & 65.83 & 72.62 \\
Bihar & 71.93 & 76.86 & 79.94 & 82.56 & 62.59 & 70.49 \\
Jharkhand & 79.14 & 82.26 & 87.03 & 88.44 & 69.96 & 75.47 \\
Rajasthan & 76.20 & 79.68 & 86.45 & 87.91 & 64.67 & 70.73 \\
UttarPradesh & 69.75 & 75.14 & 76.76 & 80.45 & 61.73 & 69.22 \\
Odisha & 80.84 & 85.75 & 87.93 & 90.72 & 72.87 & 80.42 \\
MadhyaPradesh & 79.39 & 82.85 & 87.39 & 88.67 & 70.47 & 76.52 \\
Chhattisgarh & 80.58 & 84.05 & 89.39 & 90.58 & 71.11 & 77.24 \\
Uttaranchal & 81.44 & 84.45 & 87.05 & 89.05 & 74.77 & 79.25 \\
\hline
\end{tabular}

Source: Computed from Primary Census Abstract, Census of India 2011 and 2001, Table C-8.

Decadal Growth Rate in Literacy: India, EAG and literacy in rural areas is substantially higher in Non-EAG States: Table 2 shows the decadal EAG States than Non-EAG States. On the other growth rate of literacy between 2001 and 2011 hand, in urban areas it is almost the same in in India, EAG and Non-EAG States. It clearly EAG and Non-EAG States. Among rural females, depictsthat in the last decade the growth rate of the decadal growth rate of literacy is 2.5 times 
greater in EAG States than Non-EAG States. Among rural males, it is 2.4 times higher in EAGStates compared to Non-EA G States. Among EAG States, the highest growth rate of female literacy isfound in Bihar ( 99.68 percent) followed byJharkhand ( 80.26 percent) and Uttar Pradesh
(72.13 per cent). In rural Bihar, the growth rate of female literacy between 2001 and 2011 is as high as 110.07 percent. Among EAG States, the highest decadal growth rate of male literacy in rural areas is also found in Bihar (55.55 per cent).

Table 2: Growth Rate in Literacy between 2001 and 2011 in India, EAG and Non-EAG States

\begin{tabular}{|lccccccccc|}
\hline India/State & \multicolumn{2}{c}{$\begin{array}{c}\text { Decadal Growth Rate } \\
\text { in Literacy (\%) - Total }\end{array}$} & \multicolumn{2}{c|}{$\begin{array}{c}\text { Decadal Growth Rate } \\
\text { in Literacy (\%)-Rural }\end{array}$} & \multicolumn{3}{c|}{$\begin{array}{c}\text { Decadal Growth Rate } \\
\text { in Literacy (\%) - Urban }\end{array}$} \\
\hline & Total & Male & Female & Total & Male & Female & Total & Male & Female \\
\hline India & 36.17 & 29.17 & 46.69 & 33.38 & 25.82 & 45.59 & 41.26 & 35.78 & 48.47 \\
Non-EAG States & 29.27 & 23.72 & 36.82 & 20.94 & 15.61 & 28.54 & 41.35 & 36.06 & 48.09 \\
EAG States & 47.35 & 37.13 & 65.41 & 49.66 & 37.79 & 72.41 & 41.04 & 35.11 & 49.49 \\
Bihar & 68.77 & 53.11 & 99.68 & 73.17 & 55.55 & 110.07 & 47.01 & 39.43 & 58.29 \\
Jharkhand & 55.62 & 42.31 & 80.26 & 64.12 & 46.65 & 101.24 & 39.56 & 32.88 & 49.22 \\
Rajasthan & 38.17 & 31.26 & 51.08 & 37.83 & 30.57 & 52.85 & 38.92 & 32.99 & 47.82 \\
UttarPradesh & 51.08 & 39.54 & 72.13 & 54.03 & 40.17 & 81.82 & 43.06 & 37.57 & 50.88 \\
Odisha & 34.81 & 25.83 & 48.54 & 34.35 & 24.87 & 49.27 & 36.70 & 29.94 & 45.86 \\
MadhyaPradesh & 35.64 & 27.97 & 48.29 & 36.15 & 27.35 & 52.12 & 34.65 & 29.28 & 42.07 \\
Chhattisgarh & 37.65 & 31.24 & 47.30 & 33.01 & 26.86 & 42.63 & 50.90 & 44.50 & 59.54 \\
Uttaranchal & 34.77 & 28.41 & 43.89 & 29.41 & 22.79 & 39.07 & 47.16 & 41.69 & 54.73 \\
& & & & & & & & & \\
\hline
\end{tabular}

Source: Computed from Primary Census Abstract, Census of India 2011 and 2001, Table C-8.

Gender Disparity in Literacy: India, EAG and Non-EAG States: Women are less privileged than men in most of the societies in the world. In India a girl child is discriminated even before she is born. In the last decade, the child sex ratio (Number of girls aged 0-6 years per 1000 boys of same age group) hasgone down in India and it is awfully skewed in favour of male children. The feminist interpretation of gender discrimination argues that the gendered division of labour and the control over women's sexuality reinforce the subordination of women in society and influencewomen's educational participation and their educational aspirations (Patel, 2003). We havealready got a picture of gender disparity in literacy from the Tables 1(a), 1(b)and 1(c). Figure 1 shows that the gender disparity in literacy has decreased between 2001 and 2011. Gender disparity ismuch higher in rural areas than urban areas in both EAG and Non-EAG States. Also, genderdisparity in literacy between EAG and NonEAG States is higher in rural areas compared to urban areas. 
Figure 1: Gender Disparity in Literacy in India, EAG and Non-EAG States, 2001 and 2011

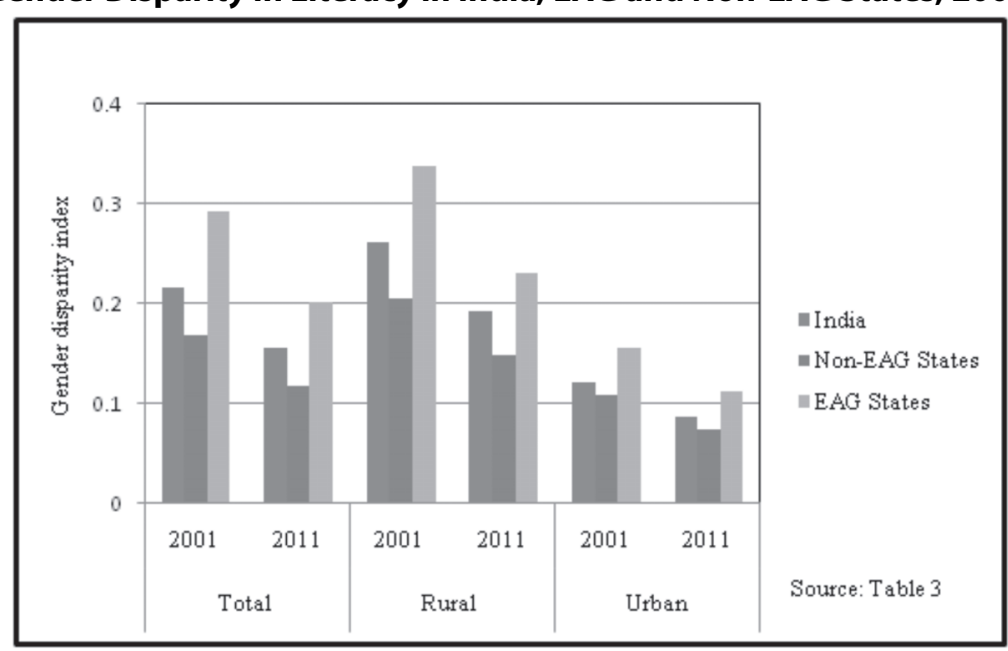

In 2001 among the EAG States, the disparity between male and female literacy was the highest in Rajasthan in both rural and urban areas. Also in 2011, it remains at the bottom among the EAGStates. In rural areas, the lowest gender difference in literacy is found in Odisha in 2011. Among the urban population in 2011, Uttaranchal showsthe minimum gender disparity in literacy. Between 2001 and 2011, malefemale literacy gap has decreased in all the EAG
States (Table 3). In three States, namely, Bihar, Jharkhand and Uttar Pradesh, gender disparity in literacy has declined sharply mainly due to the huge reduction of gender gap in literacy in rural areas. In rural areas, themaximum decrease has occurred in Jharkhand, followed by Bihar and Uttar Pradesh. On the other hand, in urban areas, the maximum decrease has taken place in Bihar, followed by Chhattisgarh and Rajasthan.

Table 3: Gender Disparity in Literacy in 2001 and 2011: India, EAG and Non-EAG States

\begin{tabular}{|lcccccc|}
\hline India/State & \multicolumn{2}{c}{ GDI-Total } & \multicolumn{2}{c}{ GDI-Rural } & \multicolumn{2}{c|}{ GDI-Urban } \\
\hline & 2001 & 2011 & 2001 & 2011 & 2001 & 2011 \\
\hline India & 0.216 & 0.156 & 0.261 & 0.192 & 0.122 & 0.087 \\
Non-EAGStates & 0.169 & 0.118 & 0.205 & 0.148 & 0.108 & 0.075 \\
EAGStates & 0.292 & 0.201 & 0.337 & 0.230 & 0.156 & 0.113 \\
Bihar & 0.331 & 0.203 & 0.362 & 0.217 & 0.165 & 0.111 \\
Jharkhand & 0.323 & 0.212 & 0.397 & 0.248 & 0.156 & 0.117 \\
Rajasthan & 0.336 & 0.270 & 0.391 & 0.316 & 0.202 & 0.156 \\
UttarPradesh & 0.292 & 0.197 & 0.344 & 0.226 & 0.145 & 0.104 \\
Odisha & 0.253 & 0.165 & 0.276 & 0.181 & 0.136 & 0.091 \\
\hline
\end{tabular}

(Contd.........) 
Table 3 (Contd.....)

\begin{tabular}{|lcccccc|}
\hline India/State & \multicolumn{2}{c}{ GDI-Total } & \multicolumn{2}{c}{ GDI-Rural } & \multicolumn{2}{c|}{ GDI-Urban } \\
& 2001 & 2011 & 2001 & 2011 & 2001 & 2011 \\
\hline Madhya Pradesh & 0.262 & 0.188 & 0.313 & 0.225 & 0.154 & 0.109 \\
Chhattisgarh & 0.256 & 0.192 & 0.282 & 0.217 & 0.166 & 0.119 \\
Uttaranchal & 0.225 & 0.159 & 0.264 & 0.189 & 0.111 & 0.087 \\
\hline
\end{tabular}

Source: Computed from Census of India 2011,Primary Census Abstract; Census of India 2001, Table C-8. Note: GDI refers to Gender Disparity Index in literacy.

Rural-Urban Differentials in Literacy: India, EAG and Non-EAG States: Literacy rate is higher in urban areas than in rural areas in India. Educational opportunities in rural India are very poor compared to urban areas. Also in urban places people are mainly engaged in tertiary and secondary sectors of economy. They require higher level of education than the workers engaged in primary sector in the villages. The rural-urban differential in literacy in the country has reduced in the last decade. It has reduced more in EAG States than in Non-EAG States between 2001 and 2011 (Figure 2). Among EAG States, the highest and the lowest rural-urban differential in literacy are found in Jharkhand and Uttaranchal, respectively, in both 2001 and 2011 censuses. According to 2011 census, there are two EAG States where rural-urban differentials in literacy are lower than Non-EAG average. These two States are Uttaranchal and Uttar Pradesh (Appendix 1). Between 2001 and 2011,unlike other EAG States, Bihar and Jharkhand have experienced a sharp decline in the rural-urban differences in literacy. 
Figure 2: Rural-Urban Differentials in Literacy in India, EAG and Non-EAG States

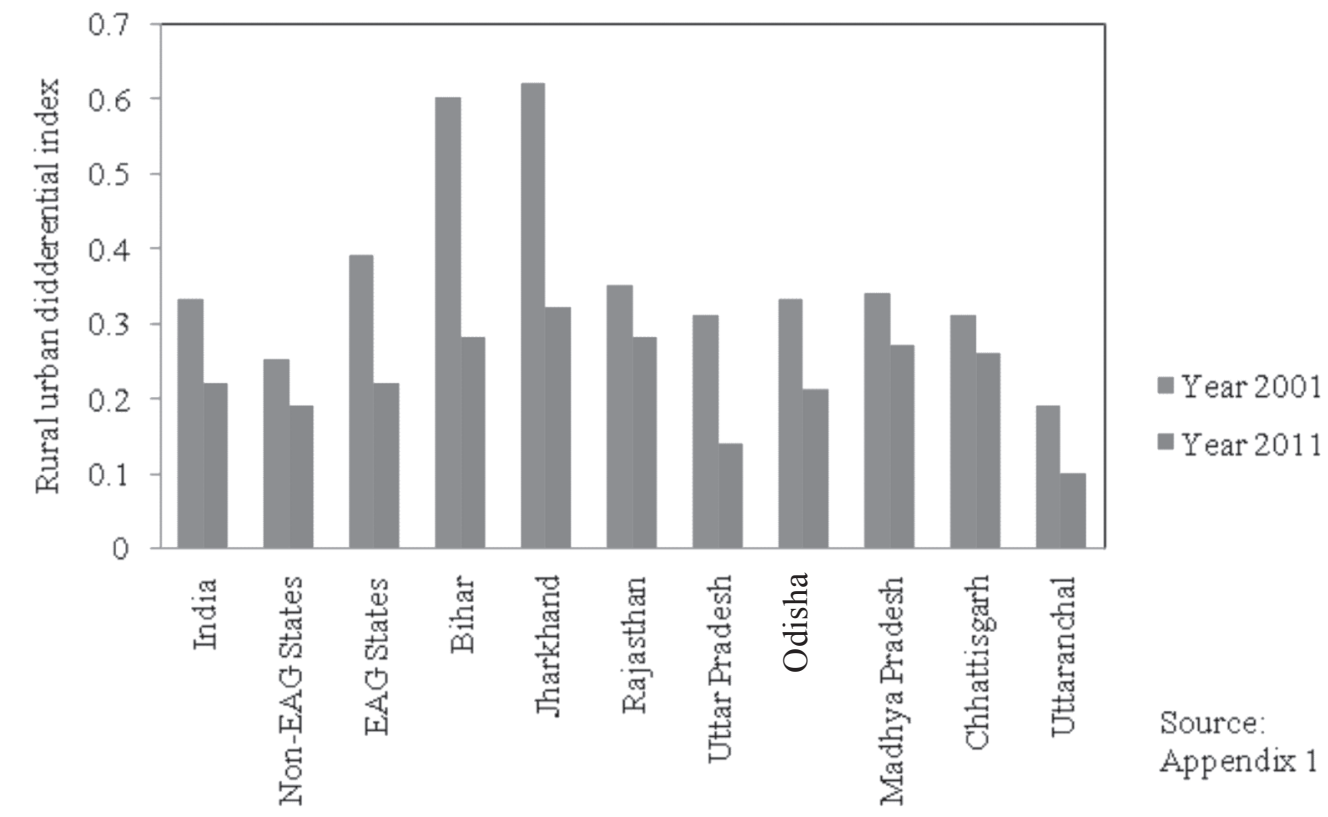

Differentials in Literacy Rate among Social Groups: India, EAG and Non-EAG States: Literacy rate varies across social groups in India. Scheduled Castes (SCs) and Scheduled Tribes (STs) are economically and socially backward classes in India. Literacy rates of SC and ST population (total, rural and urban) of EAG and Non-EAG States have been given in the appendices from 2(a) to 3(c). Literacy rate of scheduled casteand scheduled tribe population is below the national average. Literacy rate among scheduled castes has increased from 60.90 to 71.30 percent among males and 31.48 to 48.65 per cent among females in the EAG States between 2001 and 2011. During this period, among scheduled tribe population of the
EAG States, the literacy rate has increased from 56.33 to 64.94 percent among males and 28.51 to 42.75 percent among females. As expected, among both scheduled caste and scheduled tribe population, literacy rate is higher in Non-EAG States than EAG States. Considering the EAG States in 2011, the highest and the lowest literacy rates among scheduled castes are found in Uttaranchal and Bihar, respectively. Among scheduled tribes, the highest literacy rate is found in Uttaranchal and the lowest in Madhya Pradesh. According to 2011 census, the literacy rate of rural scheduled caste females in Bihar is as low as 37.41 per cent. In Rajasthan, the literacy rate among rural scheduled tribe females is only 36.10 per cent. 
Now, we will discuss the decadal growth rate in literacy among varioussocial groups based on Table 4. We have broadly categorised the population into scheduled castes, scheduled tribes and others (i.e., not under scheduled caste and scheduled tribe categories).

Table 4: Decadal Growth Rate in Literacy (\%) between 2001 and 2011 Among Social Groups: India, EAG and Non-EAG States

\begin{tabular}{|lccccccccc|}
\hline India/State & \multicolumn{3}{c}{$\begin{array}{c}\text { Decadal Growth Rate in } \\
\text { Literacy-SC }\end{array}$} & \multicolumn{3}{c}{$\begin{array}{c}\text { Decadal Growth Rate in } \\
\text { Literacy-ST }\end{array}$} & \multicolumn{3}{c|}{$\begin{array}{c}\text { Decadal Growth Ratein } \\
\text { Literacy- Others }\end{array}$} \\
\hline & $\mathrm{T}$ & $\mathrm{M}$ & $\mathrm{F}$ & $\mathrm{T}$ & $\mathrm{M}$ & $\mathrm{F}$ & $\mathrm{T}$ & $\mathrm{M}$ & $\mathrm{F}$ \\
\hline India & 51.04 & 40.15 & 69.56 & 59.83 & 46.57 & 82.92 & 32.01 & 25.89 & 40.91 \\
Non-EAGStates & 42.91 & 34.72 & 55.04 & 55.93 & 44.61 & 73.54 & 25.40 & 20.48 & 31.96 \\
EAGStates & 63.30 & 47.34 & 97.17 & 64.68 & 48.78 & 96.64 & 43.05 & 34.12 & 58.18 \\
Bihar & 120.94 & 86.01 & 219.85 & 226.72 & 172.42 & 378.15 & 62.46 & 48.49 & 89.04 \\
Jharkhand & 90.83 & 65.50 & 152.89 & 75.35 & 56.08 & 113.96 & 46.23 & 35.44 & 65.21 \\
Rajasthan & 51.38 & 40.35 & 76.04 & 60.49 & 46.93 & 94.66 & 33.05 & 27.32 & 43.07 \\
UttarPradesh & 62.19 & 45.54 & 99.11 & 1648.89 & $1403.632,270.99$ & 48.04 & 37.47 & 66.58 \\
Odisha & 50.76 & 35.66 & 77.61 & 68.08 & 46.57 & 115.09 & 25.90 & 19.47 & 34.90 \\
MadhyaPradesh & 46.16 & 35.80 & 65.41 & 59.61 & 43.23 & 91.28 & 29.61 & 23.63 & 39.02 \\
Chhattisgarh & 54.34 & 44.76 & 69.68 & 38.46 & 30.20 & 51.89 & 34.33 & 29.15 & 41.82 \\
Uttaranchal & 52.43 & 40.80 & 71.93 & 40.88 & 30.62 & 57.62 & 31.27 & 25.84 & 38.81 \\
\hline
\end{tabular}

Source: Computed from Primary Census Abstract, Census of India 2011 and 2001-C Series.

It is evident from Table 4 that in the last decade the highest growth rate in literacy has occurred among the scheduled tribes. The growth rate in literacy is higher among females than males (1.7 timeshigheramong SCs, 1.8 times greater among STs and 1.6 times higher among others at the national level). Compared to NonEAG States the decadal growth rate in literacy is higher in EAG Statesamong all the social groups. Between 2001 and 2011, the average growth rates in literacy among females of scheduled castes and scheduled tribes are 97.17 and 96.64 per cent, respectively - much higher than the growth rate of females of 'others' category (58.18 percent).

Status of Literacy in the Districts of EAG States: Findings from Census 2011: According to 2011 census, there are 277 districts under the eight EAG States. Of them in 222 districts literacy rate is below the national average (74.04 per cent) and in 134 districts the literacy rate is below the average literacy rate of the EAG States $(67.43$ per cent).Among the bottom 10 districts in literacy, three are from Madhya Pradesh (Alirajpur, J habua and Barwani), three are from Chhattisgarh (Bijapur, Dakshin Bastar Dantewada and Narayanpur), two are from Odisha (Nabarangapur and Malkangiri) and oneeach from Uttar Pradesh (Shrawasti) and J harkhand (Pakur). The lowest literacy rate is observed in Alirajpur district of Madhya Pradesh (36.10 per cent) and the highest in Khordha district of Odisha (86.88 per cent). Table 5 presents a summary of the status of literacy in the EAG States. It shows that a huge 
inter-district difference in literacy exists among the EAG States of India. While in Uttaranchal the proportion of districts where female literacy rate above the national average is 69 per cent, in Bihar, none of the districts shows female literacy rate above the national average.

Table 5: Salient Features in the Level of Literacy in the Districts of EAG States in India, 2011

\begin{tabular}{|c|c|c|}
\hline & Male & Female \\
\hline Literacy rate of India & $82.14 \%$ & $65.46 \%$ \\
\hline Average literacy rate of EAG States & $77.35 \%$ & $56.81 \%$ \\
\hline $\begin{array}{l}\text { Among EAG States name of the district with the } \\
\text { highest literacy rate }\end{array}$ & $\begin{array}{l}\text { Rudraprayag of } \\
\text { Uttaranchal (93.90\%) }\end{array}$ & $\begin{array}{l}\text { Khordah of Odisha } \\
(81.61 \%)\end{array}$ \\
\hline $\begin{array}{l}\text { Among EAG States name of the district with the } \\
\text { lowest literacy rate }\end{array}$ & \multicolumn{2}{|c|}{$\begin{array}{c}\text { Alirajpur of Madhya Alirajpur of Madhya } \\
\text { Pradesh (42.02\%) }\end{array}$} \\
\hline \multicolumn{3}{|l|}{$\begin{array}{l}\text { Number of districts in each State where literacy rate is } \\
\text { below the national average }\end{array}$} \\
\hline Bihar (Total districts-38) & 37 & 38 \\
\hline Jharkhand (Total districts-24) & 19 & 22 \\
\hline Rajasthan (Total districts-33) & 25 & 31 \\
\hline Uttar Pradesh (Total districts-71) & 53 & 61 \\
\hline Odisha (Total districts-30) & 14 & 16 \\
\hline Madhya Pradesh (Total districts-50) & 36 & 42 \\
\hline Chhattisgarh (Total districts-18) & 11 & 14 \\
\hline Uttaranchal (Total districts-13) & 2 & 4 \\
\hline
\end{tabular}

Source: Computed from Primary Census Abstract and Census of India 2011.

Table 5 shows that in Rajasthan out of 33 districts,male literacy rate in 25 districts is below the national average of 82.14 per cent and female literacy rate in 31 districts is below the national average of 65.46 per cent.

Among 277 districts, there are four districts where male literacy rate among rural population is below 50 per cent (Alirajpur and J habua of Madhya Pradesh and Dakshin Bastar Dantewada and Bijapur of (hhattisgarh). In all these four districts, the rural female literacy is below 30 per cent. Among the EAG States, the lowest rural male literacy rate isfound in Alirajpur district (37.85 percent). The lowest rural female literacy rate is found in Dakshin Bastar Dantewada (24.58 per cent). The highest rural male and rural female literacy rate is found in Rudraprayag district of Uttaranchal (93.90 per cent) and J agatsinghapur district of Odisha (80.40 per cent), respectively. In all the districts of EAG States, literacy rate among the urban males is above 60 per cent and among urban females is above 50 per cent. The lowest and the highest male literacy rates are found in Rampur district of Uttar Pradesh (60.18 per cent) and Almora of Uttarkhand (97.16 per cent). In fact among the 
EAG States, the top five districts in urban male literacy are from Uttarakhand and the bottom five districts are from Uttar Pradesh. Like male literacy rate, the lowest and the highest urban female literacy rate among the districts of EAG States are also found in Rampur district (51.44 per cent) and Almora district (91.03 per cent), respectively.

\section{Decadal Growth Rate in Literacy in EAG States} of India-A District Level Analysis: In many districts the decadal growth rate in literacy between 2001 and 2011 is very high.The growth rate in literacy is slower among the districts where literacy rate was al ready high in 2001 . The range of decadal growth rate in literacy among the districts of EAG States can easily be understood from Table 6 (a).

Table 6 (a): Names of the Districts with Highest and Lowest Decadal Growth Rate in Literacy Among EAG States (between 2001 and 2011)

\begin{tabular}{|lcc|}
\hline Total & Male & Female \\
\hline District with highest growth rate in literacy & $\begin{array}{c}\text { Kishanganj of Bihar } \\
(97.46 \%)\end{array}$ & $\begin{array}{c}\text { Kishanganj of Bihar } \\
(236.45 \%)\end{array}$ \\
District with lowest growth rate in literacy & $\begin{array}{c}\text { Garhwal of Uttarakhand } \\
(3.51 \%)\end{array}$ & $\begin{array}{c}\text { Garhwal of Uttarakhand } \\
(11.68 \%)\end{array}$ \\
\hline Rural & Male & Female \\
\hline District with highest growth rate in literacy & $\begin{array}{c}\text { Kishanganj of Bihar } \\
(110.28 \%)\end{array}$ & $\begin{array}{c}\text { Kishanganj of Bihar } \\
(289.76 \%)\end{array}$ \\
District with lowest growth rate in literacy & $\begin{array}{c}\text { Gautam Buddha Nagar } \\
\text { of UP (-2.31\%) }\end{array}$ & $\begin{array}{c}\text { Uttar Bastar Kanker of } \\
\text { Chhatisgarh (4.47\%) }\end{array}$ \\
\hline Urban & Male & Female \\
\hline District with highest growth rate in literacy & Begusarai of Bihar & Rudraprayag of \\
& $(375.14 \%)$ & Uttarakhand (432.22\%) \\
District with lowest growth rate in literacy & Uttarkashi of & Churu of Rajasthan \\
& Uttarakhand (1.84\%) & $(15.93 \%)$ \\
\hline
\end{tabular}

Source: Primary Census Abstract, Census of India 2011 and 2001- C Series. 
Maps 2 (a), 2 (b) and 2 (c) show the growth between 2001 and 2011 among the total, rural rate in literacy in the districts of EAG States and urban population, respectively.

\section{Map 2 (a): Decadal Growth Rate in Literacy in the Districts of EAG States}

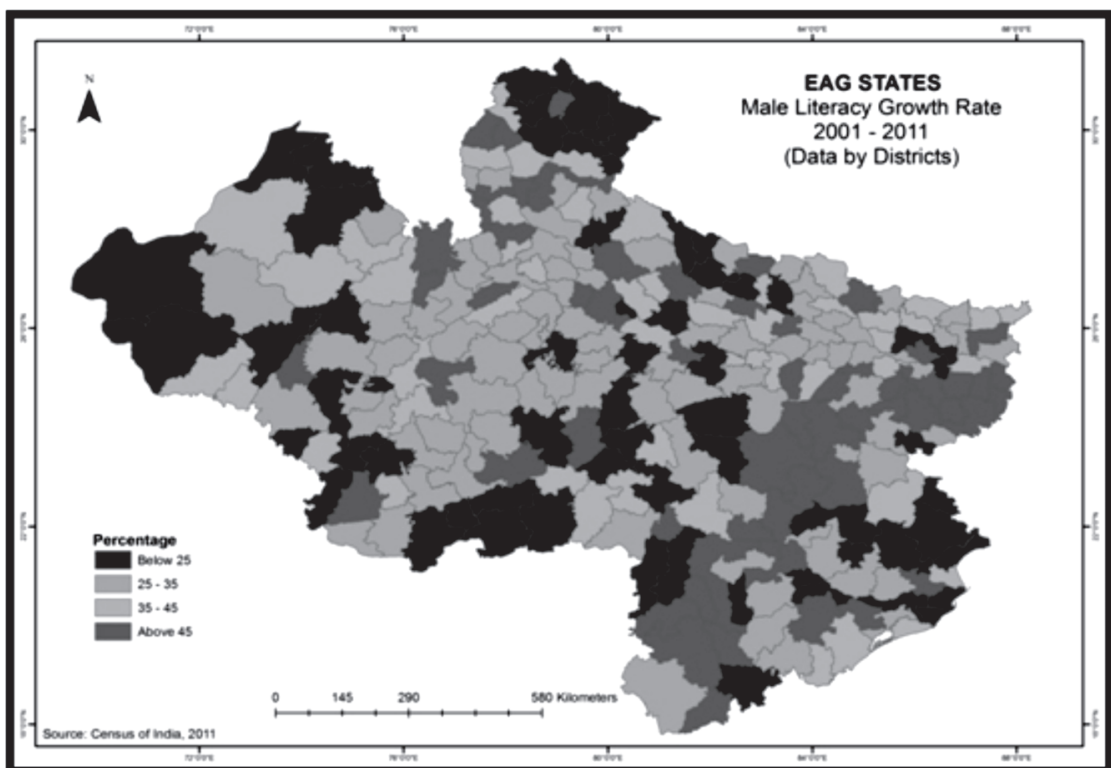

Map 2 (b): Decadal Growth Rate in Male Literacy in the Districts of EAG States

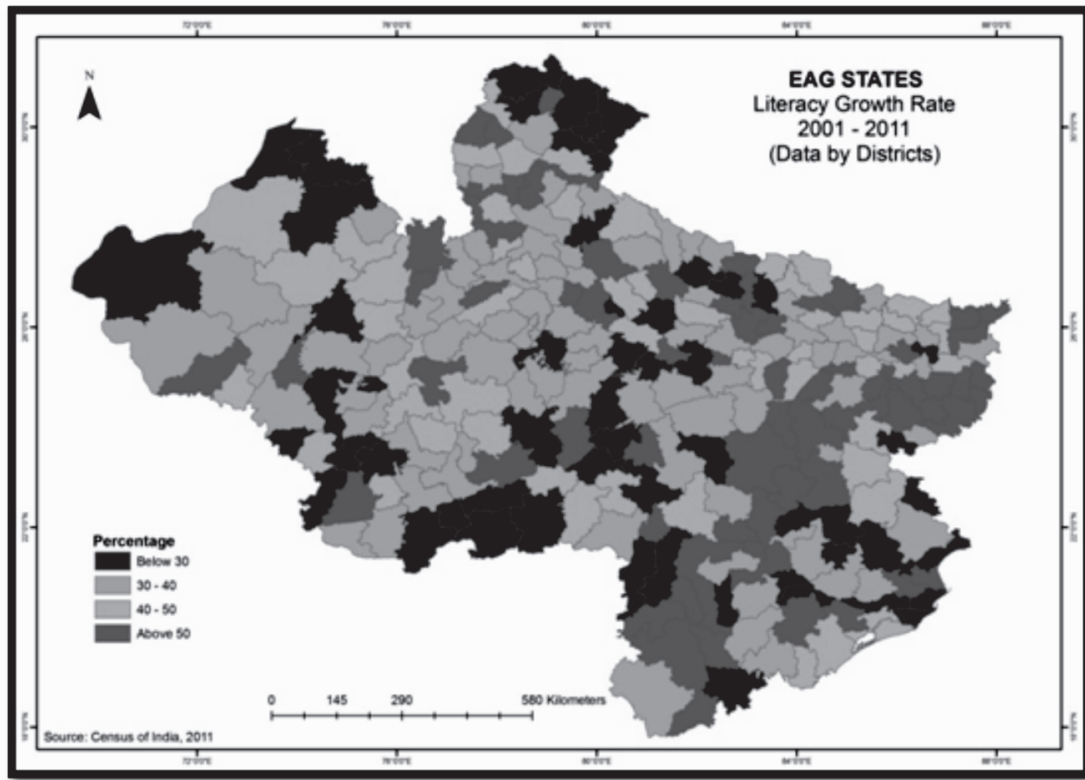

Journal of Rural Development, Vol. 36, No. 4, October- December : 2017 
Map 2 (c): Decadal Growth Rate in Female Literacy in the Districts of EAG States

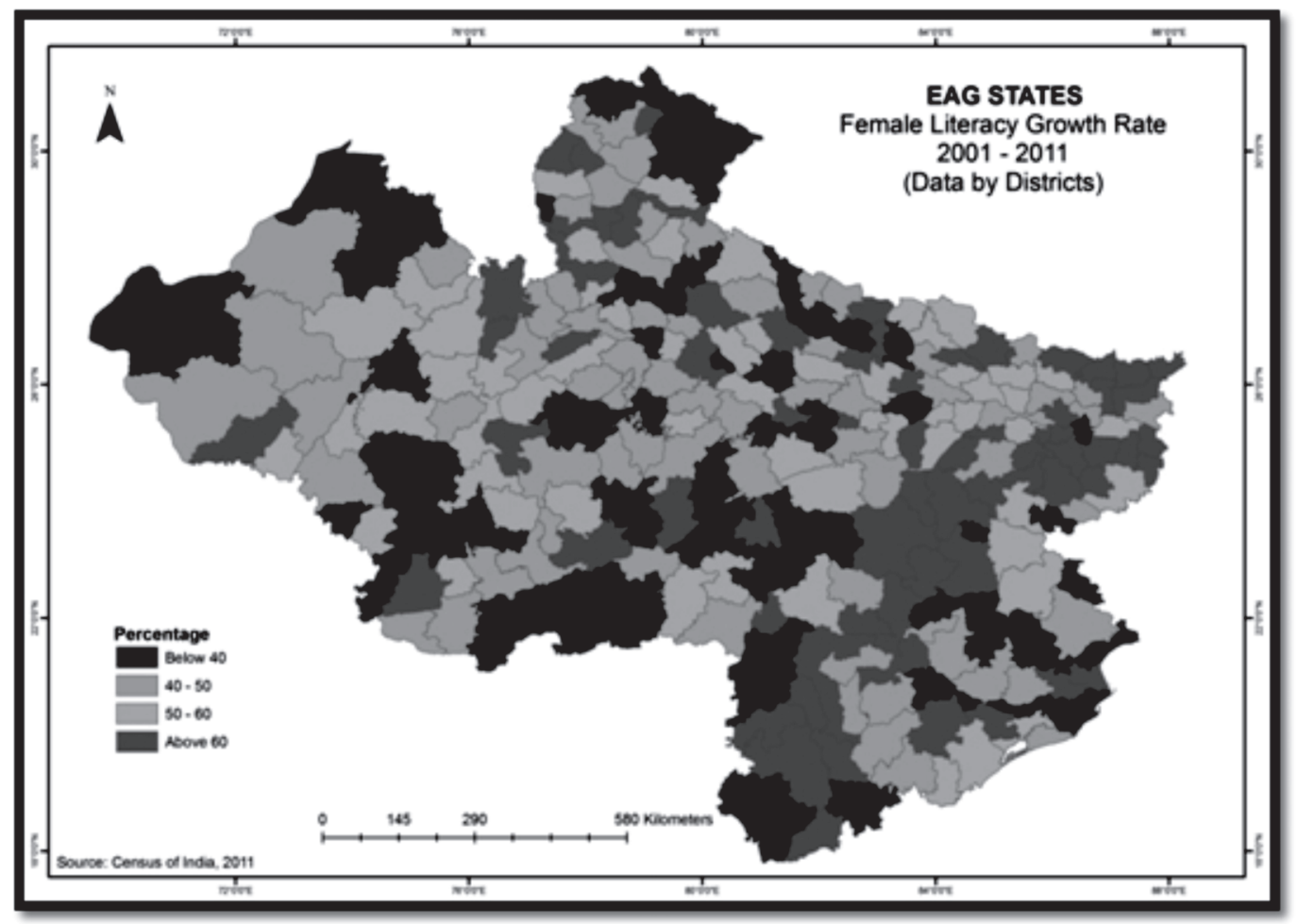

The above mapsshow the districts where decadal growth rate in literacy is above 60 per cent, particularly in Chhattisgarh, J harkhand and Bihar.

Fourteen districts of EAG States show decadal growth rate of literacy above 100 per cent among urban females. In Begusarai of Bihar and Rudraprayag of Uttarakhand, the growth rate in literacy between 2001 and 2011 is higher than 400 per cent. In these two districts, the growth rates in literacy among urban males are also exceptionally higher compared to other districts. The decadal growth rate in literacy above 100 per cent among rural females is found in 66 districts. Table 6 (b) presents some information about the growth rate in literacy of rural females. 
Table 6 (b): Variation in the Decadal Growth Rate in Literacy (Between 2001 and 2011) Among Rural Females in the Districts of EAG States in India

\begin{tabular}{|lcccc|}
\hline States with Total & Number of Districts with the following Growth Rate in Literacy \\
Districts as per 2001 & $=50 \%$ & $50.1 \%-100 \%$ & $100.1 \%-150 \%$ & $>150 \%$ \\
\hline Bihar (37) & Nil & 13 & 16 & 8 \\
Jharkhand (18) & 1 & 5 & 10 & 2 \\
Rajasthan (32) & 14 & 15 & 3 & Nil \\
UttarPradesh (70) & 8 & 43 & 15 & 4 \\
Odisha (30) & 14 & 10 & 6 & Nil \\
Madhya Pradesh (45) & 17 & 26 & 2 & Nil \\
Chhattisgarh (16) & 9 & 7 & Nil & Nil \\
Uttaranchal (13) & 8 & 5 & Nil & Nil \\
\hline
\end{tabular}

Source: Computed from Primary Census Abstract and Census of India 2011.

According to Table 6 (a), in Uttaranchal in eight districts the decadal growth rate in literacy is below 50 per cent and none of the districts shows the growth rate in literacy above 100 per cent.

Gender Disparity in Literacy Rate in EAG States of India in 2011 - A District Level Analysis: The district level analysis of gender inequality in literacy level (Table not shown) reveals that gender disparity is higher in rural areas than in urban areas. In 2011 among EAG States, there are 25 districts where the rural GDI values are above 0.3 (showing very high disparity in literacy between males and females). 22 among them are located in Rajasthan alone. The top 10 districts where gender differentials in urban literacy rate are highest are also from Rajasthan. Among the districts of EAG States, the lowest male-female difference in rural literacy rate is found in agatsinghapur of Odisha. On the other hand, the Kanpur Nagar district of Uttar Pradesh shows the minimum gender disparity in urban literacy rate. The highest gender disparity in rural and in urban literacy rates are found in J aisalmer and in Jalor districts, respectively. Maps 3 (a), 3 (b) and 3 (c) show that gender disparity in literacy is comparatively higher in most parts of Rajasthan. 
Map 3 (a): Gender Disparity in Literacy Among the Districts of EAG States, 2011

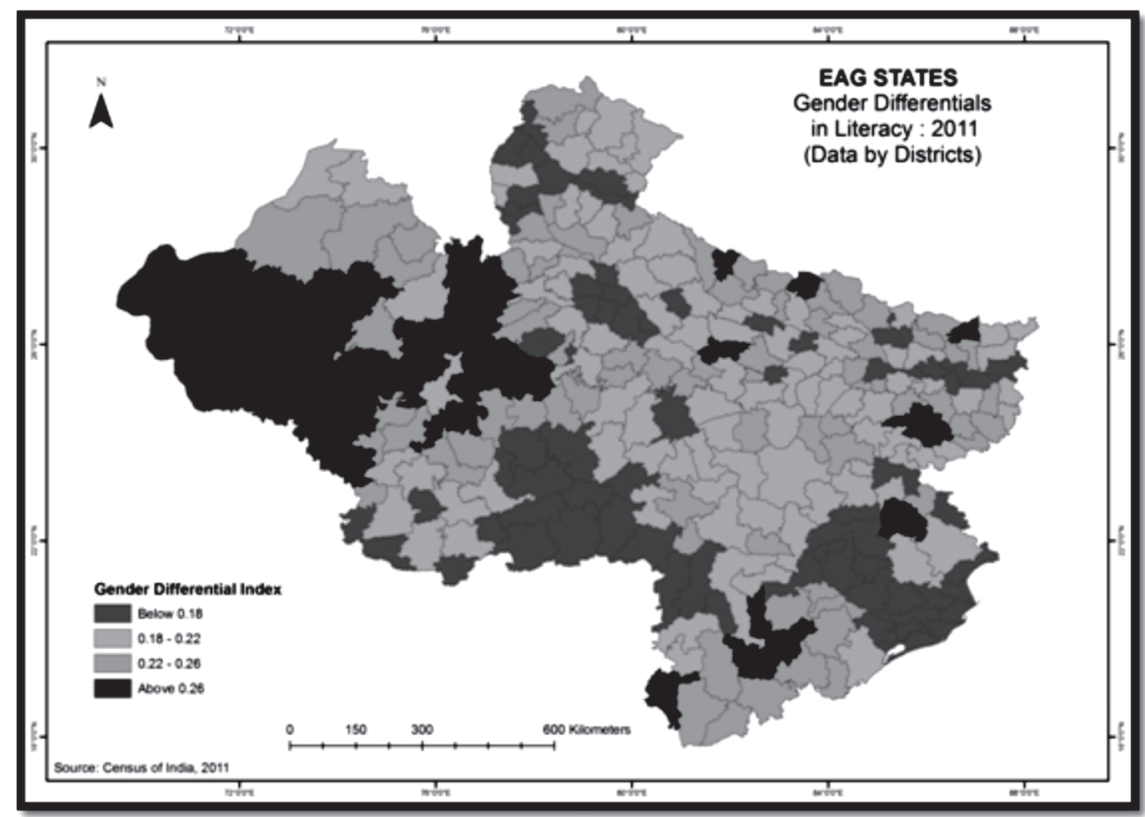

Map 3 (b): Gender Disparity in Literacy (Rural) Among the Districts of EAG States, 2011

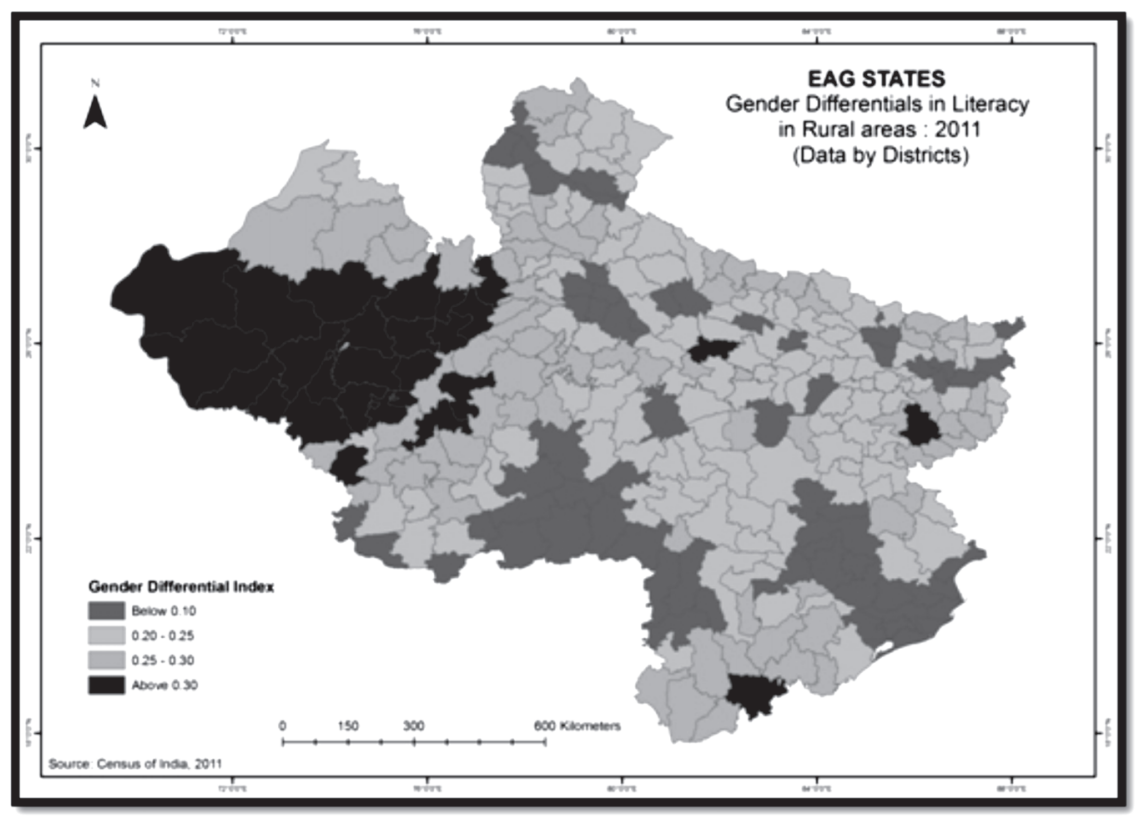

Journal of Rural Development, Vol. 36, No. 4, October-December : 2017 
3 (c): Gender Disparity in Literacy (Urban) Among the Districts of EAG States,2011

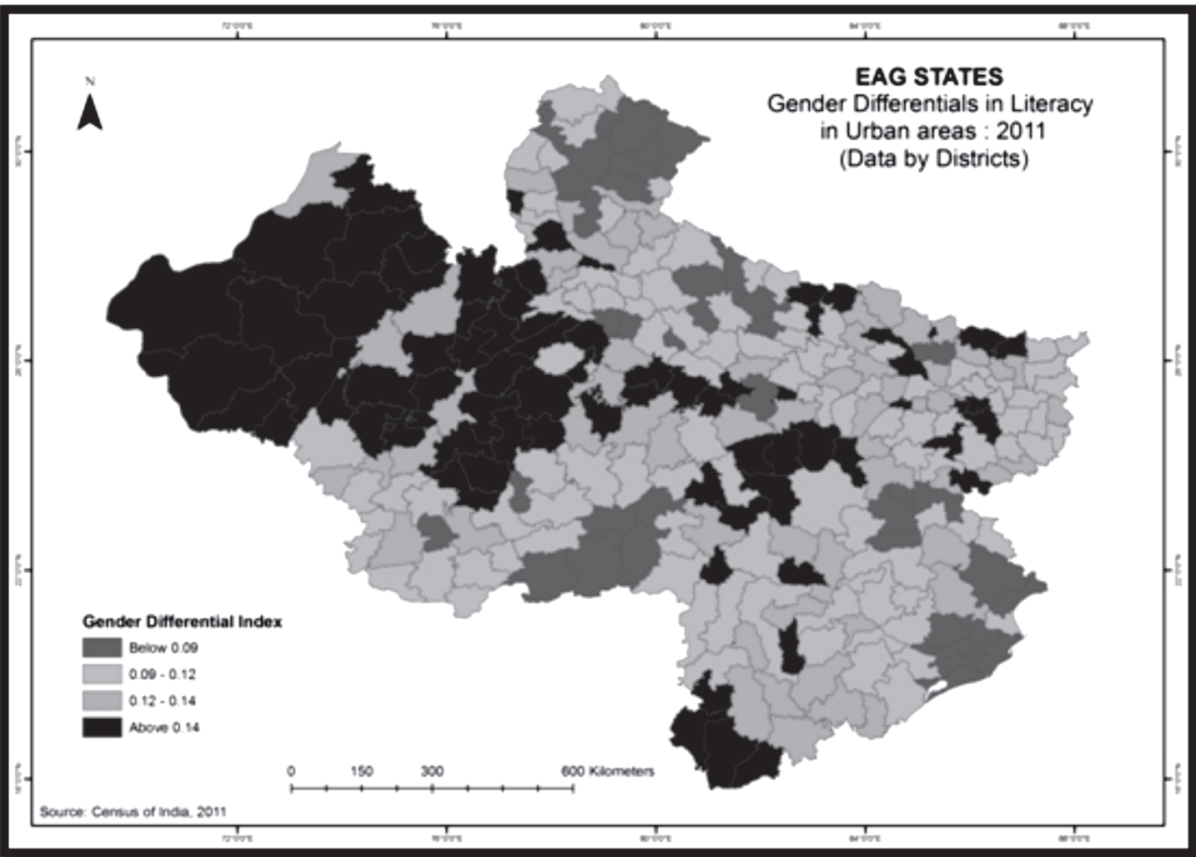

Map 4: Rural-Urban Differentials in Literacy Among the Districts of EAG States, 2011

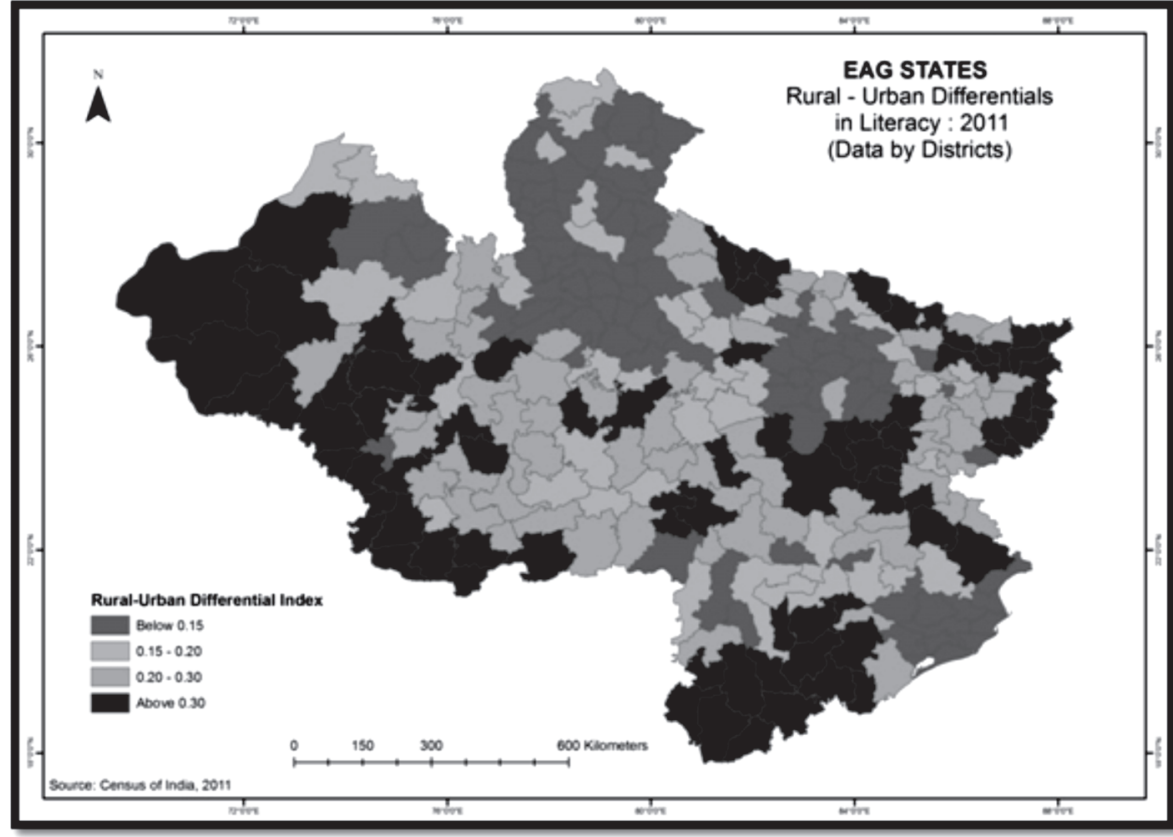

Journal of Rural Development, Vol. 36, No. 4, October-December : 2017 
Rural-Urban Differentials in Literacy Rate in EAG States of India in 2011 - A District Level Analysis: Map 4 shows the rural-urban disparity in literacy among the districts of EAG States. The above map shows that the rural-urban differential in literacy is comparatively higher in most of Rajasthan and in southern Madhya Pradesh, northern Bihar, western and north-eastern J harkhand and also in southern part of Odisha and Chhattisgarh.

According to the census 2011, among the top 10 districts of EAG States where rural-urban differential index of literacy shows negative or very low values, eight are found in UttarPradesh and the remaining two districts belong to Odisha. In Bhadrak of Odisha (RUDI is -0.05) and in Firozabad (RUDI is-0.03) and Kannauj (RUDI is -0.03 ) of Uttar Pradesh rural literacy rate is higher than urban. It is difficult to say why such anomaly exists. In the rest of districts urban literacy rate is higher than the rural literacy rate.
The highest rural-urban disparity in literacy is found in Alirajpur district of Madhya Pradesh followed by Dakshin Bastar Dantewada of Chhattisgarh and $\mathrm{J}$ habua of Madhya Pradesh. It has already been established from our analysis that gender disparity in literacy is higher in rural areas.

Literacy Rate among Rural Females of Scheduled Caste and Scheduled Tribe Categories in EAG States of India, 2011 - A District Level Analysis: In Indian society discrimination against women is a common phenomenon and the lowerfemale literacy than men is only one manifestation of such discrimination. However, rural women of scheduled caste and scheduled tribe categories are extremely disadvantaged groups of India. Therefore, in this section we will discuss the literacy status of these people. Table 7 shows the disadvantageous position of rural scheduled caste and scheduled tribe femalesin the field of literacy.

Table 7: Variation in Literacy Rate Among Different Population Groups in India, EAG and Non-EAG States, 2011

\begin{tabular}{|lccccc|}
\hline India/State & \multicolumn{5}{c|}{ Literacy Rate in \% } \\
\hline & Male & Female & $\begin{array}{c}\text { Rural } \\
\text { Female }\end{array}$ & $\begin{array}{c}\text { Rural Female } \\
\text { of SC Category }\end{array}$ & $\begin{array}{c}\text { Rural Female } \\
\text { of ST Category }\end{array}$ \\
\hline India & 82.14 & 65.46 & 58.80 & 52.56 & 49.36 \\
Non-EAGStates & 83.91 & 71.03 & 63.84 & 59.06 & 56.07 \\
EAG States & 77.35 & 56.81 & 52.26 & 46.40 & 41.21 \\
Bihar & 71.20 & 51.50 & 49.00 & 37.41 & 39.47 \\
Jharkhand & 76.84 & 55.42 & 48.91 & 40.78 & 43.94 \\
Rajasthan & 79.19 & 52.12 & 45.80 & 41.40 & 36.10 \\
Uttar Pradesh & 77.28 & 57.18 & 53.65 & 47.35 & 42.28 \\
Odisha & 81.59 & 64.01 & 60.74 & 57.59 & 39.91 \\
MadhyaPradesh & 78.73 & 59.24 & 52.43 & 50.39 & 40.15 \\
Chhattisgarh & 80.27 & 60.24 & 55.06 & 57.46 & 47.06 \\
Uttaranchal & 87.40 & 70.01 & 66.18 & 62.14 & 61.97 \\
\hline
\end{tabular}

Source: Computed from Primary Census Abstract and Census of India 2011. 
While analysing the district level literacy rate of rural female scheduled caste and scheduled tribe population, one should bevery cautious because in some districts the number of scheduled caste or scheduled tribe population is extremely low.For example, in Baghpat district of Uttar Pradesh, the literacy rate of rural scheduled tribe females is found zero. Actually, according to 2011 census, there are only 4 rural scheduled tribe females in that district and none of them are literate. Therefore, we find such an abnormal literacy rate. However, it is found that among 277 districts under EAG States, in 170 districts (61 per cent) the rural female literacy rate among scheduled caste population is less than 50 per cent. 198 districts (71 percent) under EAG States show rural female literacy rate among scheduled tribes below 50 per cent.

\section{Conclusion}

In conclusion, we will just highlight the major findings of this study. The disparity in literacy rates between EAG and Non-EAG States is still substantial.However,between 2001 and 2011 , the growth rate of rural literacy is found much higher in EAG States than Non-EAG States. In urban areas, the decadal growth rate in literacy does not show much variation between EAG and Non-EAG States. Between 2001 and 2011, gender disparity and rural-urban differentials in literacy has decreased both in EAG and NonEAGStates. In India, gender inequality in literacy is much higher in rural areas than in urban areas. In Bihar, J harkhand and Uttar Pradesh in the last decade a remarkable increase has been found in rural female literacy rate which has helped to improve the overall literacy rates in these districts. Compared to Non-EAGStates, the decadal growth rate in literacy is higher in EAG States among all the social groups - scheduled caste, scheduled tribe, and Non-SC/ST. Uttarakhand which was part of Uttar Pradesh till 2000, shows the highest literacy rate-the minimum gender disparity and the lowest rural-urban differentials among the EAG States. At district level analysis, we have found that according to 2011 census, among 277 districts under EAG States, 222 districts show literacy rate below the national average (74.04 percent). There exists a huge variation in gender disparity and rural-urban differentials in literacy rate among the districts of EAG States. Rural scheduled tribe females show an exceptionally low rate of literacy. 


\section{References}

Government of India (2001), “C-Series: Socio Cultural Tables,” Registrar General and Census Commissioner of India, New Delhi..

Government of India (2011,"State Primary Census Abstract- 2011," Registrar General and Census Commissioner of India, New Delhi.

Government of India (2011), "Union Primary Census Abstract- 2011,” Registrar General and Census Commissioner of India, New Delhi.

Government of India (2011), "Administrative Atlas of India- 2011," Registrar General and Census Commissioner of India, New Delhi.

Krishnan, G \& M Shyam (1978), "Regional Aspects of Urban-Rural Differential in Literacy in India: 1971,"The Journal of Developing Areas, Vol. 13, No. 1, pp. 11-21.

Kundu, A and Rao, J. M (1983),"Inequality in Education Development: Issues in Measurement Changing Structure and its Socio-Economic Correlates with Special Reference to India,"In Educational Planning: A Long Term Perspective(Ed), by MoonisRaza,NIEPA, New Delhi.

Patel, I (2003), "Literacy as Freedom for Women in India in Literacy as Freedom," A UNESCO Round Table Compilation, United Nations Educational, Scientific and Cultural Organization, Paris.

Sen, A (1994),"Beyond Liberalisation: Social Opportunity and Human Capability," First D. T. Lakdawala Memorial Lecture on June 29, 1994 at the Institute of Social Sciences, New Delhi.

Sopher,D E (1974),"A Measure of Disparity”, Professional Geographer, Vol.26, pp.389-92.

UNESCO (2005), “Literacy for Life, ”EFA Global Monitoring Report,2006, United Nations Educational, Scientific and Cultural Organization, Paris.

World Bank (2002), “World Development Report 1992,” Oxford University Press, New York.

Website:http://www.censusindia.gov.in/ 


\section{APPENDICES}

Appendix 1: Rural-Urban Differential in Literacy in 2001 and 2011: India, EAG and NonEAG States

\begin{tabular}{|lcc|}
\hline India/State & \multicolumn{2}{c|}{ Rural-U Differential lindex } \\
\hline & 2001 & 2011 \\
\hline India & 0.33 & 0.22 \\
Non-EAG States & 0.25 & 0.19 \\
EAG States & 0.39 & 0.22 \\
Bihar & 0.60 & 0.28 \\
Jharkhand & 0.62 & 0.32 \\
Rajasthan & 0.35 & 0.28 \\
UttarPradesh & 0.31 & 0.14 \\
Odisha & 0.33 & 0.21 \\
MadhyaPradesh & 0.34 & 0.27 \\
Chhattisgarh & 0.31 & 0.26 \\
Uttaranchal & 0.19 & 0.10 \\
\hline
\end{tabular}

Source: Computed from Census of India 2011,Primary Census Abstract and 2001, Table C-8.

Appendix 2 (a): Literacy Rate Among Scheduled Caste Population in India, EAG and NonEAG States in 2001 and 2011: Total

\begin{tabular}{|lcccccc|}
\hline India/State & \multicolumn{2}{c}{ Total Literacy } & \multicolumn{2}{c|}{ Male Literacy } & \multicolumn{2}{c|}{ Female Literacy } \\
\hline & 2001 & 2011 & 2001 & 2011 & 2001 & 2011 \\
\hline India & 54.69 & 66.07 & 66.64 & 75.17 & 41.90 & 56.46 \\
Non-EAG States & 61.48 & 71.10 & 71.75 & 78.70 & 50.74 & 63.26 \\
EAGStates & 46.88 & 60.42 & 60.90 & 71.30 & 31.48 & 48.65 \\
Bihar & 28.47 & 48.65 & 40.23 & 57.97 & 15.58 & 38.46 \\
Jharkhand & 37.56 & 55.89 & 51.59 & 66.94 & 22.55 & 44.20 \\
Rajasthan & 52.24 & 59.75 & 68.99 & 73.77 & 33.87 & 44.63 \\
UttarPradesh & 46.27 & 60.89 & 60.34 & 71.77 & 30.50 & 48.87 \\
Odisha & 55.53 & 69.02 & 70.47 & 79.21 & 40.33 & 58.76 \\
MadhyaPradesh & 58.57 & 66.16 & 72.33 & 76.72 & 43.28 & 54.70 \\
Chhattisgarh & 63.96 & 70.76 & 78.70 & 81.66 & 49.22 & 59.86 \\
Uttaranchal & 63.40 & 74.41 & 77.26 & 84.34 & 48.74 & 64.05 \\
\hline
\end{tabular}

Source: Computed from Primary Census Abstract, Census of India 2011 and 2001, Table C-8.

Appendix 2 (b): Literacy Rate Among Scheduled Caste Population in India, EAG and Non-EAG States in 2001 and 2011: Rural

\begin{tabular}{|lcccccc|}
\hline India/State & \multicolumn{2}{c}{ Total Literacy } & \multicolumn{2}{c|}{ Male Literacy } & \multicolumn{2}{c|}{ Female Literacy } \\
\hline & 2001 & 2011 & 2001 & 2011 & 2001 & 2011 \\
\hline India & 51.16 & 62.85 & 63.66 & 72.58 & 37.84 & 52.56 \\
Non-EAG States & 57.95 & 67.49 & 68.73 & 75.65 & 46.74 & 59.06 \\
\hline
\end{tabular}


Appendix 2 (b) (Contd.....)

\begin{tabular}{|lllllll|}
\hline India/State & \multicolumn{2}{c}{ Total Literacy } & \multicolumn{2}{c|}{ Male Literacy } & \multicolumn{2}{c|}{ Female Literacy } \\
\hline & 2001 & 2011 & 2001 & 2011 & 2001 & 2011 \\
\hline EAGStates & 44.37 & 58.55 & 58.70 & 69.79 & 28.72 & 46.40 \\
Bihar & 26.93 & 47.66 & 38.66 & 57.05 & 14.13 & 37.41 \\
Jharkhand & 32.52 & 52.72 & 46.57 & 64.05 & 17.73 & 40.78 \\
Rajasthan & 49.86 & 57.17 & 66.93 & 71.80 & 31.18 & 41.40 \\
UttarPradesh & 44.52 & 59.80 & 59.03 & 71.12 & 28.33 & 47.35 \\
Odisha & 54.23 & 68.05 & 69.51 & 78.45 & 38.76 & 57.59 \\
MadhyaPradesh & 55.39 & 62.72 & 69.73 & 74.05 & 39.44 & 50.39 \\
Chhattisgarh & 62.47 & 68.97 & 77.81 & 80.48 & 47.27 & 57.46 \\
Uttaranchal & 61.53 & 73.12 & 76.34 & 83.81 & 46.11 & 62.14 \\
\hline
\end{tabular}

Source: Computed from Primary Census Abstract, Census of India 2011 and 2001, Table C-8.

Appendix 2 (c): Literacy Rate Among Scheduled Caste Population in India, EAG and NonEAG States in 2001 and 2011: Urban

\begin{tabular}{|lcccccc|}
\hline India/State & \multicolumn{2}{c}{ Total Literacy } & \multicolumn{2}{c|}{ Male Literacy } & \multicolumn{2}{c|}{ Female Literacy } \\
\hline & 2011 & 2001 & 2011 & 2001 & 2011 & 2001 \\
\hline India & 76.17 & 68.12 & 83.32 & 77.93 & 68.64 & 57.49 \\
Non-EAG States & 79.13 & 71.53 & 85.47 & 80.27 & 72.58 & 62.25 \\
EAGStates & 69.91 & 61.25 & 78.90 & 73.36 & 60.07 & 47.61 \\
Bihar & 60.64 & 49.11 & 68.96 & 60.63 & 51.35 & 35.70 \\
Jharkhand & 67.34 & 58.14 & 77.25 & 71.24 & 56.68 & 43.11 \\
Rajasthan & 68.64 & 61.35 & 80.58 & 76.83 & 55.78 & 44.22 \\
UttarPradesh & 67.47 & 58.17 & 75.65 & 69.08 & 58.20 & 45.51 \\
Odisha & 75.18 & 65.31 & 83.97 & 77.56 & 66.23 & 52.38 \\
Madhya Pradesh & 75.13 & 68.02 & 83.71 & 80.06 & 65.88 & 54.69 \\
Chhattisgarh & 76.57 & 69.28 & 85.48 & 81.81 & 67.61 & 56.31 \\
Uttaranchal & 79.12 & 72.01 & 86.23 & 81.29 & 71.29 & 61.42 \\
\hline
\end{tabular}

Source: Computed from Primary Census Abstract, Census of India 2011 and 2001, Table C-8.

Appendix 3 (a): Literacy Rate Among Scheduled Tribe Population in India, EAG and NonEAG States in 2001 and 2011: Total

\begin{tabular}{|lcccccc|}
\hline India/State & \multicolumn{2}{c}{ Total Literacy } & \multicolumn{2}{c}{ Male Literacy } & \multicolumn{2}{c|}{ Female Literacy } \\
\hline & 2001 & 2011 & 2001 & 2011 & 2001 & 2011 \\
\hline India & 47.10 & 58.95 & 59.17 & 68.51 & 34.76 & 49.36 \\
Non-EAGStates & 51.54 & 64.12 & 61.94 & 72.11 & 40.87 & 56.07 \\
EAGStates & 42.54 & 53.85 & 56.33 & 64.94 & 28.51 & 42.75 \\
Bihar & 28.17 & 51.08 & 39.76 & 61.31 & 15.54 & 40.38 \\
Jharkhand & 40.67 & 57.13 & 53.98 & 68.17 & 27.21 & 46.20 \\
Rajasthan & 44.66 & 52.80 & 62.10 & 67.62 & 26.16 & 37.27 \\
UttarPradesh & 35.13 & 55.68 & 48.45 & 67.08 & 20.70 & 43.72 \\
\hline
\end{tabular}


Appendix 3 (a) (Contd.....)

\begin{tabular}{|lcccccc|}
\hline India/State & \multicolumn{2}{c}{ Total Literacy } & \multicolumn{2}{c|}{ Male Literacy } & \multicolumn{2}{c|}{ Female Literacy } \\
\hline & 2001 & 2011 & 2001 & 2011 & 2001 & 2011 \\
\hline Odisha & 37.37 & 52.24 & 51.48 & 63.70 & 23.37 & 41.20 \\
Madhya Pradesh & 41.16 & 50.55 & 53.55 & 59.55 & 28.44 & 41.47 \\
Chhattisgarh & 52.09 & 59.09 & 65.04 & 69.67 & 39.35 & 48.76 \\
Uttaranchal & 63.23 & 73.88 & 76.39 & 83.56 & 49.37 & 63.89 \\
\hline
\end{tabular}

Source: Computed from Primary Census Abstract, Census of India 2011 and 2001, Table C-8.

Appendix 3 (b): Literacy Rate Among Scheduled Tribe Population in India, EAG and Non-EAG States in 2001 and 2011: Rural

\begin{tabular}{|lllllll|}
\hline India/State & \multicolumn{2}{c}{ Total Literacy } & \multicolumn{2}{c|}{ Male Literacy } & \multicolumn{2}{c|}{ Female Literacy } \\
\hline & 2001 & 2011 & 2001 & 2011 & 2001 & 2011 \\
\hline India & 45.02 & 56.89 & 57.39 & 66.80 & 32.44 & 49.36 \\
Non-EAGStates & 48.98 & 61.65 & 59.72 & 70.06 & 37.97 & 56.07 \\
EAGStates & 41.16 & 52.49 & 55.09 & 63.78 & 27.06 & 41.21 \\
Bihar & 25.91 & 50.32 & 37.57 & 60.70 & 13.30 & 39.47 \\
Jharkhand & 38.08 & 55.22 & 51.67 & 66.60 & 24.38 & 43.94 \\
Rajasthan & 43.70 & 51.73 & 61.23 & 66.70 & 25.22 & 36.10 \\
UttarPradesh & 32.99 & 54.48 & 46.71 & 66.23 & 18.34 & 42.28 \\
Odisha & 36.13 & 51.08 & 50.35 & 62.72 & 22.07 & 39.91 \\
MadhyaPradesh & 40.01 & 49.32 & 52.51 & 58.43 & 27.24 & 40.15 \\
Chhattisgarh & 50.95 & 57.57 & 63.96 & 68.36 & 38.21 & 47.06 \\
Uttaranchal & 61.65 & 72.39 & 75.29 & 82.49 & 47.36 & 61.97 \\
\hline
\end{tabular}

Source: Computed from Primary Census Abstract, Census of India 2011 and 2001, Table C-8.

Appendix 3 (c): Literacy Rate Among Scheduled Tribe Population in India, EAG and NonEAG States in 2001 and 2011: Urban

\begin{tabular}{|lllllll|}
\hline India/State & \multicolumn{2}{c}{ Total Literacy } & \multicolumn{2}{c|}{ Male Literacy } & \multicolumn{2}{c|}{ Female Literacy } \\
\hline & 2001 & 2011 & 2001 & 2011 & 2001 & 2011 \\
\hline India & 69.09 & 76.78 & 77.77 & 83.16 & 59.87 & 70.32 \\
Non-EAGStates & 72.93 & 79.94 & 80.21 & 85.25 & 65.32 & 74.60 \\
EAGStates & 62.56 & 71.04 & 73.72 & 79.39 & 50.39 & 62.43 \\
Bihar & 65.67 & 65.33 & 74.18 & 72.50 & 55.28 & 57.62 \\
Jharkhand & 67.80 & 75.44 & 77.83 & 83.22 & 57.38 & 67.78 \\
Rajasthan & 60.79 & 68.99 & 75.74 & 81.03 & 42.97 & 55.57 \\
UttarPradesh & 51.10 & 66.97 & 60.61 & 74.81 & 39.54 & 58.02 \\
Odisha & 58.12 & 69.08 & 69.80 & 77.67 & 45.77 & 60.46 \\
Madhya Pradesh & 57.23 & 66.73 & 67.47 & 73.99 & 45.89 & 59.16 \\
Chhattisgarh & 71.71 & 76.94 & 82.87 & 84.92 & 59.77 & 68.97 \\
Uttaranchal & 85.91 & 88.33 & 91.55 & 93.73 & 79.48 & 82.63 \\
\hline
\end{tabular}

Source: Computed from Primary Census Abstract, Census of India 2011 and 2001, Table C-8. 